\title{
Management Commitments in the Policy Implementation of Exclusive Breast-Feeding for Working Mothers: A Study in Textile Industries in Central Java
}

\author{
Noveri Aisyaroh ${ }^{1}$, Emi Sutrisminah ${ }^{1} \&$ Widayati $^{1}$ \\ ${ }^{1}$ Universitas Islam Sultan Agung, Jl. Kaligawe Raya, Semarang, Central Java 50112, Indonesia \\ Correspondence: Noveri Aisyaroh, Universitas Islam Sultan Agung, Jl. Kaligawe Raya, Semarang, Central Java \\ 50112, Indonesia. E-mail: noveriaisyaroh.unissula@gmail.com
}

Received: October 19, 2018 Accepted: March 4, 2019 Online Published: March 15, 2019

doi:10.5539/gjhs.v11n4p63

URL: https://doi.org/10.5539/gjhs.v11n4p63

\begin{abstract}
The high rates of neonatal, infant and children mortality in Indonesia indicate that the MDGs 2017 target has not been fully achieved. One of the prevention measures for mortality is exclusive breastfeeding. In Indonesia, the breast-feeding coverage has not reached the expected target because one of the factors is working mothers. Most working mothers stop breastfeeding or start mixing baby feeding before the baby is 6 months old. Here, the commitment of company managers in implementing government policies will increase exclusive breast-feeding coverage. This type of research uses descriptive analysis with documentation study methods, observation, interviews and questionnaires in 4 textile companies in Semarang City, Semarang Regency and Pekalongan. The number of respondents 99 people consists of women workers, administrators of workplaces and health workers in the workplace. The results of the study show that $49.5 \%$ of companies are committed to supporting government policies by facilitating leave and that there are arrangements for working hours that are in accordance with the rules, and that $50.5 \%$ do not support this matter and do not fully support government policy. Furthermore, the results of this study are complemented by interviews with HRD and management related to breastfeeding policy and working conditions.
\end{abstract}

Keywords: management commitment, exclusive breast-feeding policy, women workers, textile companies

\section{Introduction}

Indicators of the success of the child health program refer to the Millennium Development Goals (MDGs) 2015 document. The MDGs target sets a 14/1,000 neonatal mortality rate, a 23/1,000 infant mortality rate, and a toddler mortality rate of 32/1,000 live births. The causes of neonatal death are still many because many factors are associated with neonatal deaths, both factors in the mother, child, environment and health service factors (Rutstein, 2000; Caldwell, 1979; Haines et al., 2007). Many actions are relatively inexpensive and easily applied to improve the health and survival of newborns. One of them is giving breast-feeding immediately after birth or called early initiation of breastfeeding as well as exclusive breast-feeding (Fikawati \& Syafiq, 2010; Edmond et al., 2006; Baker, Sanei, \& Franklin, 2006; Madhu, Chowdary, \& Masthi, 2009). This is supported by the statement of the United Nations Childrens Fund (UNICEF), that as many as 30,000 infant deaths in Indonesia and 10 million deaths of children under five in the world each year. This is supposedly able to prevent through exclusive breast-feeding for six months from the date of birth, without having to provide additional food and drinks to the baby (Edmond et al., 2006).

Breast-feeding is the best food for newborns, both babies born enough months (matur) and less months (premature). Various research results show that breast-feeding provides many physiological (Heinig, \& Dewey, 1997; Heinig, \& Dewey, 1996; Heinig, 2001; De Carvalho, Hall, \& Harvey, 1981; Field, 2005; Hanson, 1998; Oddy, 2002) and emotional benefits both for mother and infant (Mezzacappa \& Katkin, 2002; Dennis \& McQueen, 2009; Strathearn, Mamun, Najman, \& O'Callaghan, 2009). The World Health Organization (WHO) recommends exclusive breast-feeding for at least the first 6 months, and similar recommendations are also supported by the American Academy of Pediatrics (AAP), Academy of Breastfeeding Medicine, as well as the Indonesian Pediatrician Association . Breast-feeding coverage in Indonesia alone has not reached the expected number of $80 \%$. According to Indonesian Health Data in 2011, exclusive breast-feeding in Indonesia only covers $61.5 \%$ and in 
CENTRAL JAVA only 57.8\% (Statistics Indonesia, 2013). Based on data from NSS in collaboration with Balitbangkes and Hellen Keller International, the problems that result in the still low use of exclusive breast-feeding in Indonesia are socio-cultural factors, awareness of the importance of breast-feeding, health services and health workers who have not fully supported government regulation concerning the breast-feeding, the incessant promotion of milk formula and working mother (Ministry of Health. 2011).

Breastfeeding is the right of every mother, including working mothers. However, working mothers are still considered as one of the factors causing the high rate of failure of breastfeeding (Yilmaz, Gürakan, Akgün, \& Ozbek, 2002; Johnston \& Esposito, 2007; Witters-Green, 2003; Chen, Wu, \& Chie, 2006), whereas in industrialized countries $45-60 \%$ of the workforce are women of productive age. The 2012 Indonesian Demographic Health Survey (IDHS) shows that $55 \%$ of women in Indonesia are working and most are in healthy reproductive age. The factors that hinder the success of breastfeeding in working mothers are the short time to work leave, lack of workplace support, short breaks at work (not enough time to giving breastfeeding for infants), lack of room to express breastfeeding, conflict between mother's desire between maintaining work performance and breast-feeding production (Hirani \& Karmaliani, 2013; Fein \& Roe, 1998; Ryan \& Martinez, 1989; Barber-Madden, Petschek, \& Pakter, 1987; Atabay et al., 2015). Most mothers stop breastfeeding or start mixing baby feeding before the baby is 6 months old to complement breast milk. Even many return to work a few weeks after delivery, so they make their lives and health themselves and their babies at risk. Breastfeeding mothers must be prepared if they will return to work so they can still provide breast-feeding to their babies. Nursing mothers who work need clean environment, comfortable atmosphere, and private, a more flexible work schedule, so that the mother can flush breast-feeding calmly and store her breast-feeding temporarily in an adequate workplace. Beyond the medical pathway, the Indonesian government is committed to reducing infant mortality and supporting exclusive breast-feeding by issuing various policies through Government Regulation No. 33 of 2012 concerning Exclusive Breast-feeding and Minister of Health Regulation No. 15 of 2013 concerning Tata Ways to Provide Special Breastfeeding and/or Breastfeeding Facilities. In Minister of Health Regulation No. 15 of 2013 Chapter II concerning the exclusive breast-feeding support, especially in article 3 (1), the management of the workplace and the organizer of the public facilities must support an exclusive breast-feeding program, with the form of support contained in article 3 paragraph (2). This study analyzes the commitment of company managers in implementing exclusive breast-feeding administration policies. This study was designed differently than some previous studies. Among other things, this study focuses more on aspects of the company's commitment to providing more space for breastfeeding mothers to provide exclusive milk for their babies. Previous studies focused more on experience and research on the perspective of nursing mothers. The advantage side of this research is to make it easier to describe the level of corporate commitment for breastfeeding mothers, as well as an assessment of their policies and implementation. In addition, studies on management are considered more able to provide a comprehensive understanding because this study involves many textile companies in several regions in CENTRAL JAVA.

\section{Research Methods}

\subsection{Research Type}

This type of research uses descriptive analysis on the commitment/workplace management policy in the CENTRAL JAVA textile company.

\subsection{Research Location}

This research was carried out in 4 companies located in Semarang City, Semarang Regency and Pekalongan.

\subsection{Sampling}

The total sample used was 99 respondents consisting of 91 female workers, 4 workplace administrators and 4 health workers in the workplace.

\subsection{Data Collection}

The data was collected with questionnaire and interview method. Interviews were also conducted with managers/HRDs and health workers.

\section{Results and Discussion}

\subsection{Workplace Management Commitment/Policy}

Commitment/policy of the workplace manager in relation to the policy on leave arrangements and working hour arrangements for female workers. 
Table 1. Commitment/Management Policy

\begin{tabular}{lll}
\hline Policy & $\boldsymbol{f}$ & $\%$ \\
\hline Do not support & 46 & 50.5 \\
Support & 45 & 49.5 \\
\hline Total & $\mathbf{9 1}$ & $\mathbf{1 0 0}$ \\
\hline
\end{tabular}

It can be explained that textile companies by $50.5 \%$ do not support government policies, and $48.5 \%$ support government policies. Based on table 1. that $49.5 \%$ of companies are committed to supporting government policies by facilitating leave and there are arrangements for working hours that are in accordance with the rules, and $50.5 \%$ do not support in this case it does not fully support government policy.

The quantitative results for this commitment are supported by the results of the FGD, which are carried out on HRD and health workers regarding the commitment of managers in implementing government policies related to working hours regulation can be seen from the following statement:

[Policy] in the company for maternity leave, we apply the rules set by the government, in this case the policy of labor offices, which is one and a half months before and one and a half months after giving birth. For mothers who are still breastfeeding, we give the opportunity to flush during the break time, there are no restrictions on milking for the mother from the permission with her supervisor, then related to the rules, we do not have written rules about the policy. (R.P.1)

[Our policy] for maternity leave in the company is the same [with other companies] throughout CENTRAL JAVA, which is one and a half months before and one and a half months after giving birth. For breastfeeding mothers when flushing there are no restrictions, as long as the permission with the supervisor and bring the clinic card to be flushed to the lactation room available at the clinic. For written regulations there is a SOP that is attached to the lactation room. (R.P.2)

Both quantitatively and qualitatively, it can be concluded that the company has not fully supported the implementation of government policies for breastfeeding mothers. The rules for leave have been applied in accordance with government regulations, but what remains a problem is that the company does not have a written regulation issued by the government, so that the implementation of the company has not fully implemented the policy, such as the absence of written Standard Operating and Procedures and/or SOPs but not yet socialized optimally.

The success of policy implementation is determined by the number of actors or organizational units involved as well as various complex variables that are interconnected with each other. This policy is a policy that involves various agencies such as the Health Service, Regional Government, health facilities, as well as public and community place organizers.

Based on information from the HRD and health personnel obtained:

.... get an invitation to socialize breast-feeding policy but not given facilities to implement the policy and no follow-up .... (R.P.1)

... never received an invitation to socialize breast-feeding policy so that it only applies according to Bayer's request ... (R.P.2)

.... was once invited to attend socialization, attended training, and was once visited by the Health Office and Puskesmas (health center) .... this clinic works with the puskesmas for KIA KB services .... (R.P.3)

In 2012, a Government Regulation concerning the Giving of Exclusive Breastfeeding (PP No. 33 of 2012) was issued. This rule regulates the duties and responsibilities of the government and regional governments in the development of the ASI program, including establishing national and regional policies, carrying out advocacy and outreach and supervising the exclusive breast-feeding program. Following up on the PP, Minister of Health Regulation No. 15 of 2013 was issued on February 18, 2013 concerning the procedures for providing special facilities for breastfeeding and/or breast-feeding and the Minister of Health Regulation No. 39 of 2013 dated May 17, 2013 concerning infant formula and other products.

Coverage of exclusive breast-feeding for infants 0-6 months fluctuates. The results of the 2007 Indonesian Demographic and Health Survey (IDHS) showed an exclusive breast-feeding coverage of 0 - 6 months infants of $32 \%$ which showed a significant increase to $42 \%$ in 2012 . However, the targets that have been set have not been 
achieved. Thus, in order to support the success of breastfeeding, up to 2013, the number of counselors who had been trained was 4,324 people.

\section{Assessment of Workplace Conditions}

Based on the results of the FGD conducted on the HRD and health workers regarding workplace conditions including the number of employees, working hours and hazards can be seen from the following statement:

For the number of our employees, most of them are women, approximately 1492 of the total 1502 employees, the number of breastfeeding mothers currently available is 45, but the active ones are 4-5 people. The working hours follow the same government rules throughout CENTRAL JAVA, namely 07.30 - 16.00, break from 11:30 to 13:00, overtime there is a break at 15.30 - 16.30. For potential hazards in the workplace, namely dust and chemical fabric, so the place is red in the lab room (2nd floor office). (R.P.1)

Our employees with a reproductive age of 150 people, the number of breastfeeding mothers currently available is 40 people and actively flush 3-4 people. Working hours are 7:30 a.m. - 4:00 p.m., resting at 11:30 p.m., 1:00 p.m., there is a break at 15.30 - 16.30. For potential workplace hazards namely dust from fabric that is harmful to breathing, so our employees must wear masks. (R.P.2)

$60 \%$ of women working here, around 540 of the total 900 employees, the majority of reproductive age, and breastfeeding junctions currently reach 126 people, the average mother who flushes to the clinic is 17 people/day. Working hours follow the same government rules throughout CENTRAL JAVA, we use the rule 3 times shif that is morning at 06.00-14.00, noon $14.00-22.00$ and 22.00 - 06.00, the rest time is 1 hour each. The potential danger is fabric dust, so it is mandatory wearing a mask (RP4)

It can be concluded that the majority of mothers working in textile factories are women of reproductive age. Arrangement of working hours in the company has followed the rules of the Manpower and Transmigration Office in 2003. As explained in the law that the Working Hours for workers in the private sector are regulated in Law No. 13 of 2003 concerning manpower, especially articles 77 through article 85. Article 77 paragraph 1, Law No.13/2003 requires every entrepreneur to implement working hours. The provisions of these working hours have been arranged in 2 systems as mentioned above, namely: 7 working hours in 1 day or 40 working hours in 1 week for 6 working days in 1 week; or 8 working hours in 1 day or 40 working hours in 1 week for 5 working days in 1 week. Hazard potential for textile factory employees is air pollution because fabric dust contains chemicals, of course this is very dangerous for the respiratory health and skin health of employees, so the company makes a rule that every employee wears a mask, with the aim of minimizing dust contamination in the workspace.

Hong Kong Christian Industrial Committee reports that the working environment conditions in 3 garment industries in China that supply garment products for retail in Germany are as follows between factory owners and workers lacking awareness about occupational health and safety (Ascloy, N., Dent, K., \& Haan, E. D. (2004; Hurley, 2004). In the three factories surveyed there were no drills for fire fighting, workers complained about air condition and poor ventilation. The placement of machines that were too tight resulted in an increase in temperature in the workplace. Workers in textile industries have skin allergies and respiratory problems due to sewing some types of fabric that have a lot of fabric dust (floating fiber). Other sources of danger are ergonomic problems such as length of work time (sitting and standing) repetition of work movements and others. Mizdraković, Trajković and Đorđević (2006) empirically shows that potential sources of danger in the garment industry are in cutting, sewing and finishing spaces.

\section{Conclusions and Suggestions}

The commitment of company managers has not fully implemented the policy of providing exclusive breast-feeding for working mothers. Written regulations and policies must be understood by all elements of the company. As a form of commitment, company managers need to make operational standard procedures and regulations that support exclusive breast-feeding that can be understood and applied in the company.

\section{Acknowledgments}

This research was carried out with the assistance of the Directorate of Research and Community Service, Directorate General of Research and Development Strengthening, Ministry of Research, Technology and Higher Education which has funded this activity, H. Anis Malik Thoha, Lc., MA., Ph.D as Chancellor of Islamic University Sultan Agung Semarang, Dr. dr. Setyo Trisnadi, SH., Sp. KF as Dean of the Faculty of Medicine Unissula, Machfudloh, S.SiT., MH. Kes as Chair of the Diploma Study Program of Midwifery.

\section{Competing Interests Statement}

The authors declare that there are no competing or potential conflicts of interest. 


\section{References}

Ascloy, N., Dent, K., \& Haan, E. D. (2004). Critical issues for the garment industry. Somo bulletins on issues in garments \& textiles, (1), 1-88.

Atabay, E., Moreno, G., Nandi, A., Kranz, G., Vincent, I., Assi, T. M., ... \& Heymann, S. J. (2015). Facilitating working mothers' ability to breastfeed: global trends in guaranteeing breastfeeding breaks at work, 1995-2014. Journal of Human Lactation, 31(1), 81-88. https://doi.org/10.1177/0890334414554806

Baker, E. J., Sanei, L. C., \& Franklin, N. (2006). Early initiation of and exclusive breastfeeding in large-scale community-based programmes in Bolivia and Madagascar. Journal of health, population, and nutrition, 24(4), 530-539. Retrieved from https://www.ncbi.nlm.nih.gov/pmc/articles/PMC3001157/.

Barber-Madden, R., Petschek, M. A., \& Pakter, J. (1987). Breastfeeding and the working mother: barriers and intervention strategies. Journal of Public Health Policy, 8(4), 531-541. https://doi.org/10.2307/3342277

Caldwell, J. C. (1979). Education as a factor in mortality decline an examination of Nigerian data. Population studies, 395-413. https://doi.org/10.2307/2173888

Chen, Y. C., Wu, Y. C., \& Chie, W. C. (2006). Effects of work-related factors on the breastfeeding behavior of working mothers in a Taiwanese semiconductor manufacturer: a cross-sectional survey. BMC Public Health, 6(1), 160. https://doi.org/10.1186/1471-2458-6-160

De Carvalho, M., Hall, M., \& Harvey, D. (1981). Effects of water supplementation on physiological jaundice in breast-fed babies. Archives of disease in childhood, 56(7), 568-569. https://doi.org/10.1136/adc.56.7.568

Dennis, C. L., \& McQueen, K. (2009). The relationship between infant-feeding outcomes and postpartum depression: a qualitative systematic review. Pediatrics, 123(4), e736-e751. https://doi.org/10.1542/peds.2008-1629

Edmond, K. M., Zandoh, C., Quigley, M. A., Amenga-Etego, S., Owusu-Agyei, S., \& Kirkwood, B. R. (2006). Delayed breastfeeding initiation increases risk of neonatal mortality. Pediatrics, 117(3), e380-e386. https://doi.org/10.1542/peds.2005-1496

Fein, S. B., \& Roe, B. (1998). The effect of work status on initiation and duration of breast-feeding. American journal of public health, 88(7), 1042-1046. https://doi.org/10.2105/AJPH.88.7.1042

Field, C. J. (2005). The immunological components of human milk and their effect on immune development in infants. The Journal of nutrition, 135(1), 1-4. https://doi.org/10.1093/jn/135.1.1

Fikawati, S., \& Syafiq, A. (2010). Kajian implementasi dan kebijakan air susu ibu eksklusif dan inisiasi menyusu dini di Indonesia. Makara kesehatan, 14(1), 17-24.

Haines, A., Sanders, D., Lehmann, U., Rowe, A. K., Lawn, J. E., Jan, S., ... \& Bhutta, Z. (2007). Achieving child survival goals: potential contribution of community health workers. The Lancet, 369(9579), 2121-2131. https://doi.org/10.1016/S0140-6736(07)60325-0

Hanson, L. A. (1998). Breastfeeding provides passive and likely long-lasting active immunity. Annals of Allergy, Asthma \& Immunology, 81(6), 523-537. https://doi.org/10.1016/S0140-6736(07)60325-0

Heinig, M. J. (2001). Host defense benefits of breastfeeding for the infant: effect of breastfeeding duration and

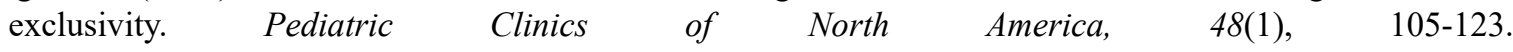
https://doi.org/10.1016/S0031-3955(05)70288-1

Heinig, M. J., \& Dewey, K. G. (1996). Health advantages of breast feeding for infants: a critical review. Nutrition research reviews, 9(1), 89-110. https://doi.org/10.1079/NRR19960007

Heinig, M. J., \& Dewey, K. G. (1997). Health effects of breast feeding for mothers: a critical review. Nutrition research reviews, 10(1), 35-56. https://doi.org/10.1079/NRR19970004

Hirani, S. A. A., \& Karmaliani, R. (2013). Evidence based workplace interventions to promote breastfeeding practices among Pakistani working mothers. Women and birth, 26(1), 10-16. https://doi.org/10.1016/j.wombi.2011.12.005

Hurley, J. (2004). Garment Industry Subcontracting Chains and Working Conditions. In Garment Report Clean Clothes Campaign (pp 104-134). Clean Clothes. Retrieved from https://cleanclothes.org/resources/national-cccs/garment-report-www.pdf/at_download/file

Johnston, M. L., \& Esposito, N. (2007). Barriers and facilitators for breastfeeding among working women in the 
United States. Journal of Obstetric, Gynecologic, \& Neonatal Nursing, 36(1), 9-20. https://doi.org/10.1111/j.1552-6909.2006.00109.x

Joint Regulation of the Minister of State for Women Empowerment, Minister of Manpower and Transmigration, and Minister of Health. No. 48/Men.PP/XII/2008, No. Per.27/Men/XII/2008, No. 1177/Menkes/PB/XII/2008 concerning Increasing the Giving of Breast-feeding during Work Time at Work. https://doi.org/10.1166/asl.2017.9189

Madhu, K., Chowdary, S., \& Masthi, R. (2009). Breast feeding practices and newborn care in rural areas: a descriptive cross-sectional study. Indian journal of community medicine: official publication of Indian Association of Preventive \& Social Medicine, 34(3), 243. https://doi.org/10.4103/0970-0218.55292

Mezzacappa, E. S., \& Katkin, E. S. (2002). Breast-feeding is associated with reduced perceived stress and negative mood in mothers. Health Psychology, 21(2), 187. https://doi.org/10.1037/0278-6133.21.2.187

Ministry of Health of the Republic of Indonesia -Directorate General of Nutrition and Maternal and Child Health. (2011). Management Guidelines for Breast-feeding at the Workplace. Jakarta: Indonesian Ministry of Health.

Ministry of Health of the Republic of Indonesia. (2012). Government Regulation No. 33 of 2012 concerning Giving Exclusive Breast-feeding. Jakarta: Ministry of Health of the Republic of Indonesia.

Ministry of Health of the Republic of Indonesia. (2012). Profile of Indonesian Health Data in 2011. Jakarta: Ministry of Health of the Republic of Indonesia.

Ministry of Health of the Republic of Indonesia. (2013). Regulation of the Minister of Health of the Republic of Indonesia Number 15 of 2013 concerning Procedures for Provision of Breastfeeding and/or Breastfeeding Special Facilities. Jakarta: Ministry of Health of the Republic of Indonesia.

Mizdraković, M., Trajković, C., \& Đorđević, D. (2006). Anti-felting shrinkage finishing of knitted wool fabric. Tekstilna industrija, 54(10-12), 17-23.

Statistics Indonesia (Badan Pusat Statistik-BPS). (2013). National Population and Family Planning Board $(\mathrm{BKKBN})$, and Kementerian Kesehatan (Kemenkes-MOH), and ICF International. 2013. Indonesia Demographic and Health Survey 2012. Jakarta, Indonesia: BPS, BKKBN, Kemenkes, and ICF International.

Oddy, W. H. (2002). The impact of breastmilk on infant and child health. Breastfeeding Review, 10(3), 5.

Rutstein, S. O. (2000). Factors associated with trends in infant and child mortality in developing countries during the 1990s. Bulletin of the World Health Organization, 78, 1256-1270.

Ryan, A. S., \& Martinez, G. A. (1989). Breast-feeding and the working mother: a profile. Pediatrics, 83(4), 524-531.

Strathearn, L., Mamun, A. A., Najman, J. M., \& O'Callaghan, M. J. (2009). Does breastfeeding protect against substantiated child abuse and neglect? A 15-year cohort study. Pediatrics, 123(2), 483-493. https://doi.org/10.1542/peds.2007-3546

Witters-Green, R. (2003). Increasing breastfeeding rates in working mothers. Families, Systems, \& Health, 21(4), 415. https://doi.org/10.1037/h0089617

Yilmaz, G., Gürakan, B., Akgün, S., \& Ozbek, N. (2002). Factors influencing breastfeeding for working mothers. The Turkish journal of pediatrics, 44(1), 30-34.

\section{Copyrights}

Copyright for this article is retained by the author(s), with first publication rights granted to the journal.

This is an open-access article distributed under the terms and conditions of the Creative Commons Attribution license (http://creativecommons.org/licenses/by/4.0/). 